\title{
Iodine Intake Estimation from the Consumption of Instant Noodles, Drinking Water and Household Salt in Indonesia
}

\author{
Aang Sutrisna ${ }^{1, *}$, Jacky Knowles ${ }^{1}$, Abas Basuni ${ }^{2}$, Ravi Menon ${ }^{1}$ and Anung Sugihantono ${ }^{3}$ \\ 1 Global Alliance for Improved Nutrition (GAIN), Menara Palma 7th Floor, Jln. HR Rasuna Said Blok X2 kav 6, \\ Jakarta 12950, Indonesia; jacky@jackyknowlesconsultancy.com (J.K.); rmenon@gainhealth.org (R.M.) \\ 2 National Institute for Health Research and Development, Jln. Percetakan Negara No. 29, \\ Jakarta 10560, Indonesia; abas1952@gmail.com \\ 3 Ministry of Health Indonesia Direktorat Jenderal Kesehatan Masyarakat, Jln. HR. Rasuna Said Blok X-5 \\ Kav. 4-9, Jakarta 12950, Indonesia; sugihantonoa@yahoo.com \\ * Correspondence: asutrisna@gainhealth.org; Tel.: +62-21-5795-6031; Fax: +62-21-5795-6032
}

Received: 26 December 2017; Accepted: 7 March 2018; Published: 8 March 2018

\begin{abstract}
The objective of this study was to assess the contribution of iodine intake from iodised household salt, iodised salt in instant noodles, and iodine in ground water in five regions of Indonesia. Secondary data analysis was performed using the 2013 Primary Health Research Survey, the 2014 Total Diet Study, and data from food industry research. Iodine intake was estimated among 2719 children, 10-12 years of age (SAC), 13,233 women of reproductive age (WRA), and 578 pregnant women (PW). Combined estimated iodine intake from the three stated sources met $78 \%, 70 \%$, and $41 \%$ of iodine requirements for SAC, WRA and PW, respectively. Household salt iodine contributed about half of the iodine requirements for SAC (49\%) and WRA (48\%) and a quarter for PW (28\%). The following variations were found: for population group, the percentage of estimated dietary iodine requirements met by instant noodle consumption was significantly higher among SAC; for region, estimated iodine intake was significantly higher from ground water for WRA in Java, and from household salt for SAC and WRA in Kalimantan and Java; and for household socio-economic status (SES), iodine intake from household salt was significantly higher in the highest SES households. Enforcement of clear implementing regulations for iodisation of household and food industry salt will promote optimal iodine intake among all population groups with different diets.
\end{abstract}

Keywords: modelling iodine intake; iodine intake; iodised salt; food industry; Indonesia

\section{Introduction}

Iodine is an element essential for mammalian life; it is absorbed by the thyroid gland where it is converted into thyroid hormones which are required for growth and development throughout life. Iodine is especially important for ensuring optimal foetal brain development during pregnancy [1-3]. The World Health Organization (WHO) recommended daily nutrient intake (RNI) for iodine is $90 \mu \mathrm{g}$ for children 0-5 years of age, $120 \mu \mathrm{g}$ for school age children (SAC) 6-12 years of age, $150 \mu \mathrm{g}$ for children and adults 12 years of age and over, and $250 \mu \mathrm{g}$ for pregnant women (PW) and lactating women $[1,4]$. Universal Salt Iodisation (USI) has been recommended by WHO and UNICEF as the most cost-effective public health strategy for the prevention of iodine deficiency disorders (IDD). A target of $90 \%$ households using adequately iodised salt was set by WHO, UNICEF and the International Council for Control of IDD to indicate achievement of USI. While optimal iodine intake is defined at the population level by a median urinary iodine concentration (MUIC) of 100-299 $\mu \mathrm{g} / \mathrm{L}, 100-199 \mu \mathrm{g} / \mathrm{L}$, $150-249 \mu \mathrm{g} / \mathrm{L}$ and $\geq 100 \mu \mathrm{g} / \mathrm{L}$ for SAC, women of reproductive age (WRA), PW and lactating women, respectively [4]. 
Iodine deficiency in Indonesia was previously assessed to be a moderate to severe problem, based on the prevalence of goiter [5]. Therefore, national legislation for USI was introduced to combat the problem in 1994 [6]. Indonesian standards define adequately iodised household salt as salt with $>30 \mathrm{mg} / \mathrm{kg}$ potassium iodate, equivalent to approximately $18 \mathrm{mg} / \mathrm{kg}$ iodine [7]. Based on a quantitative iodine analysis in salt samples from the Indonesia Primary Health Research Surveys-Riset Kesehatan Dasar (Riskesdas) - in 2007 and 2013, the percentage of households using salt with adequate iodine content decreased from $62.8 \%$ of households in 2007, to 55.1\% in 2013 [8,9]. However, the percentage of households using salt with at least some added iodine ( $>5 \mathrm{mg} / \mathrm{kg}$ iodine) was $92 \%$ in both years. Despite household coverage with adequately iodised salt being well below the international target of $90 \%$, population level iodine status was found to be within the optimal range in the 2013 Riskesdas. The MUICs for SAC, WRA, PW and lactating women were $215 \mu \mathrm{g} / \mathrm{L}, 190 \mu \mathrm{g} / \mathrm{L}, 163 \mu \mathrm{g} / \mathrm{L}$ and $164 \mu \mathrm{g} / \mathrm{L}$, respectively [8]. The previous Riskesdas survey in 2007 also reported adequate iodine status among SAC, with the MUIC found to be $224 \mu \mathrm{g} / \mathrm{L}$ [9], indicating that optimal iodine intake had been maintained among this group.

Although correlation analyses from Riskesdas 2013 indicated some association between iodine intake (assessed as UIC) and the level of iodine in household salt on a national level [10], the district and national median UICs were still higher than might be expected if additional dietary iodine was from the iodisation of household salt only. This statement is based on the low coverage of adequately iodised household salt and known shifts in dietary habits away from the consumption of household salt. Nationally, the Ministry of Trade and National Bureau of Statistics data show a progressive shift in salt supply from cooking and table salt to food industry salt, which has become increasingly apparent since 2011 [11]. This is in line with the country's rapid transformation to an urban economy [12,13]. Urbanization, increasing incomes, and associated changing lifestyles are known to be driving a demand shift in Indonesia and other countries in Asia towards processed foods [14,15], along with an associated expansion of food processing, procurement and retailing, economic growth and foreign investment, and mass media [16,17].

It was therefore postulated that other sources of dietary iodine, including food sources of iodised salt, were likely contributing to iodine status findings in the 2013 survey. In Indonesia, there is widespread consumption of noodles which are known to be largely manufactured with iodised salt [18]. There are also reports of iodine in ground water (non-packaged drinking water) consumed by household members.

The Indonesian Presidential Decree Number 69/1994 on USI requires the use of iodised salt in all foods for human and animal consumption and in the food and animal feed industries [6]. However, there are currently no implementation regulations for the food industry component of this decree which means that the food industry's use of iodised salt is not monitored and is likely to be inconsistent. An investigation of food industry practices was conducted by PT Clarity Research Indonesia in 2013 with the support of the Ministry of Health, the National Agency of Drug and Food Control (BPOM) and the Global Alliance for Improved Nutrition (GAIN) [18]. The main findings from industrially processed food producers who participated in the study were that iodised salt was being used in the production of over $90 \%$ of the market share of chilli sauce and bread (about $10 \%$ of the total bread market) and in the production of approximately two thirds of the market share of instant noodles. Based on consumption data, instant noodles were the largest contributor to dietary salt intake of the products investigated, which also included food seasoning products, biscuits and soy sauce.

This paper reports on data from the 2013 Riskesdas and the 2014 Total Diet Study [19] (Survei Konsumi Makanan Individu, SKMI), which was conducted in a sub-sample of approximately $69 \%$ of Riskesdas households. This paper assesses and describes the relative contributions of household salt, instant noodles and non-packaged drinking water as dietary sources of iodine among school-age children, 10-12 years of age, WRA, and PW in Indonesia. It aims to provide this information to the national programme for the elimination of iodine deficiency. 


\section{Materials and Methods}

Estimation of iodine intake from different sources was conducted through a secondary analysis of data from the cross-sectional Riskesdas and SKMI, combined with additional information on instant noodles from supermarket product surveys, the PT Clarity Research report [18], and different investment reports, to estimate market share [20,21]. Estimation of iodine intake from instant noodle consumption was conducted by multiplied estimated iodine content from the PT Clarity Research report and product survey with the frequency of consumption from Riskesdas. Estimation of iodine intake from household salt and non-packaged drinking water was conducted by multiplied estimated daily consumption from SKMI with iodine content from Riskesdas.

The sampled population for both Riskesdas and SKMI was households in 33 provinces and 497 districts/cities in Indonesia. The SKMI 2014 included 51,127 households, selected using random systematic selection from the 294,959 households in the total Riskesdas 2013 sample. An independently selected subset of 11,430 households from Riskesdas 2013 was targeted for the collection of household salt and quantitative analysis of iodine content. A further subset of 3028 households was targeted for non-packaged drinking water. The iodine content of salt and water was assessed using titration [22,23]. Estimates of iodine intake from the consumption of instant noodles, non-packaged drinking water, and household salt were calculated for 2719 SAC, 10-12 years of age, 13,233 WRA and 578 PW. These estimates were calculated for the respective population groups resident in the Riskesdas households selected for the collection and analysis of household salt.

The socio-economic status (SES) of each individual in the combined dataset was categorised into three groups based on the calculated wealth quintile index from Riskesdas 2013. The wealth quintile indices 1 and 2 were categorised as the lowest economic status (SES-1) for this study, index 3 was categorised as an intermediate economic status (SES-2) and indices 4 and 5 were categorised as the highest economic status (SES-3).

The typical frequency of instant noodle consumption (number of packets) was available for Riskesdas 2013 respondents who were 10 years of age and above. Iodine intake from instant noodles was estimated using the following steps:

1. Estimation of salt content per packet of instant noodles:

a. Data on typical sodium content and instant noodle packet weight were collected for multiple product types, differing in packet weight and sodium content per unit weight from the two producers: Indofood Sukes Makmur and Wings Group. These producers supply almost $90 \%$ of the instant noodle market in Indonesia $[20,24]$ and the products included were from their four best-selling brands [21]. These were three Indofood brands-Indomie (seven product types), Supermi (two types) and Sarimi (two types)—and one Wings group brand: Mi Sedap (four product types).

b. The sodium content per packet was converted to the equivalent average salt content for each of the four brands using a 2.5 conversion factor (sodium contributes approximately $40 \%$ to the molecular weight of salt). An assumption was made that salt is the source of almost all sodium in instant noodle packets. Indonesian noodles typically contain monosodium glutamate and sodium compounds as preservatives. It was not possible to determine the exact amount; however, it is relatively small and sodium from salt is the major contributor to total sodium content. The salt content is from both the dried noodle and in the flavouring sachet.

2. Estimation of iodine content per packet of instant noodle. The iodine content per 1 gram of salt in instant noodles was estimated based on available information on whether the producer used iodised salt in the production of noodles and/or the spice mix. Where iodised salt was used, a salt iodine level equivalent to the minimum national salt iodisation standard $(18 \mathrm{mg} / \mathrm{kg}$ or $18 \mu \mathrm{g} / \mathrm{g}$ ) [7] was assumed. Information from the salt supplier's Certificates of Analysis for 10 
instant noodle product lines indicated that salt contained at least $18 \mathrm{mg} / \mathrm{kg}$ iodine, and in $40 \%$ of samples, the level was greater than $23 \mathrm{mg} / \mathrm{kg}$ iodine [18].

3. The average milligrams sodium/packet, grams salt/packet and assumed micrograms iodine/packet were calculated after weighting the results for each brand by the market share for that brand, scaled up to assume that these brands covered $100 \%$ of the market.

4. Categorisation of the weekly amount (number of packets) of instant noodles typically consumed was conducted by taking the reported frequency of instant noodles consumption and converting it into a category of likely weekly consumption. The reported frequency of consumption options from the questionnaire were $>1$ time/day, 1 time/day, 3-6 times/week, 1-2 times/week, and $<3$ times/month; these were assigned to the categories 10, 7, 4.5, 1.5, and 0.5 packages per week, respectively. The conversion from $>1$ packet/day to 10 packets per week was based on the reported average of 1.48 packets/day consumed by SKMI respondents who consumed instant noodles every day $(1.48 \times 7=10.4)[19]$.

Based on the average weekly consumption estimates, the associated potential iodine intakes (from point 2) were calculated and used to estimate the percent of the recommended nutrient intake (RNI) for iodine that could be met for each population group.

The Wings group did not participate in the PT Clarity study; therefore, this paper used the conservative assumption that Wings group noodles (Mi Sedap) were not produced with iodised salt. The discussion section includes comments on current knowledge about this (gained after the analyses in this manuscript were completed) and the implications for the overall contribution of instant noodles to dietary iodine intake.

Twenty-four hour dietary recall data from SKMI were used to calculate the median non-packaged water (mL/day) and the median salt (g/day) consumption for SAC, WRA and PW for each of the following five regions: Sumatra, Java, Kalimantan, Sulawesi and Bali-Papua.

The analysed iodine content of non-packaged drinking water was available for a sub-set of Riskesdas households; however, the available data did not allow for links to be made with households in the SKMI dataset. Therefore, the median iodine content of non-packaged drinking water by region was applied to all households without the result in the respective region. The regional median household non-packaged water iodine content was multiplied by the mean daily quantity of non-packaged water consumed for each population group to obtain an estimate of typical daily iodine intake from non-packaged drinking water by population group within each region.

SES data were only available within the available Riskesdas dataset; therefore, the median household iodine content of non-packaged drinking water by SES group (from Riskesdas) was multiplied by the median daily consumption of non-packaged water for each population group in the region where the household was located (from SKMI).

Iodine intake from household salt for each population group by region and SES group was estimated using a similar method as for water. The analysed iodine content of household salt was available for a large sub-set of Riskesdas households; however, as above, it was not possible to link these households to the households in the SKMI dataset. Therefore, the regional median iodine content of salt (from Riskesdas) was applied to the household without the result and multiplied by the median daily quantity of household salt consumed (from SKMI) for each population group in the same region to obtain an estimate of typical daily iodine intake from household salt by population group and region. In addition, the median iodine content of household salt by SES group (from Riskesdas) was multiplied by the median typical daily consumption of household salt (from SKMI) for the region where the household was located.

Statistical analyses were conducted using Stata Statistical Software: Release 12 (StataCorp. 2011, College Station, TX, USA). Final analyses were adjusted with consideration of the sample design and associated data weighting [8]. Normality was tested using the Shapiro-Wilks test. Descriptive statistics were used to present the outcome variables, using medians and inter-quartile ranges. The significance of differences between groups was assessed based on non-overlapping $95 \%$ confidence intervals 
around the mean. For regional analyses of all data for PW and data for non-packaged water iodine for SAC, the sample size for several regions was less than 50. In these cases, results are only shown for the national level estimates.

\section{Results}

\subsection{Estimated Iodine Intake from the Consumption of Instant Noodles}

Table 1 shows the outcome of the retail market-based survey for the salt and iodine contents of the leading brands of instant noodles, accounting for approximately $87 \%$ of the market. The sodium content of the instant noodles from supermarket product surveys ranged between 1095 and $1308 \mathrm{mg}$ per packet. An overall average of $1256 \mathrm{mg}$ sodium was determined after adjusting for the respective market share of each brand and scaling up to $100 \%$ of the market. The average salt content was estimated to be $3.14 \mathrm{~g} /$ packet, with an associated average iodine content of $46.5 \mu \mathrm{g}$ per packet, based on data available at the time of the analyses.

Table 1. Estimated salt and iodine contents of the most popular brands of instant noodles.

\begin{tabular}{|c|c|c|c|c|c|}
\hline Instant Noodle Brand & $\begin{array}{l}2013 \text { Estimated } \\
\text { Market Share * }\end{array}$ & $\begin{array}{l}\text { Average Sodium } \\
\text { (mg)/Packet } \\
\text { Instant Noodles }\end{array}$ & $\begin{array}{c}\text { Estimated Salt } \\
\text { (g)/Packet Instant } \\
\text { Noodles }\end{array}$ & $\begin{array}{l}\text { Iodine } \mu \mathrm{g} / \mathrm{g} \text { Salt in } \\
\text { Instant Noodles }^{\dagger}\end{array}$ & $\begin{array}{l}\text { Iodine } \mu \mathrm{g} / \text { Packet } \\
\text { Instant Noodles }\end{array}$ \\
\hline Indomie & $69.0 \%$ & 1251 & 3.13 & 18.0 & 56.3 \\
\hline Supermi & $1.8 \%$ & 1095 & 2.74 & 18.0 & 49.3 \\
\hline Sarimi & $1.0 \%$ & 1125 & 2.81 & 18.0 & 50.6 \\
\hline Total market share & $86.6 \%$ & & & & \\
\hline
\end{tabular}

* Based on JP Morgan data for 2013 market share and Top Brand breakdown of the relative share for each of the three Indofood brands $[18,21] ;{ }^{\dagger}$ Estimates are based on the reported use of iodised salt (no available information for Mi Sedap, Wings Group at the time of the analysis) and an assumed level of salt iodine that meets the national minimum standard (18 mg/ $\mathrm{kg}$ iodine), verified by Certificates of Analysis at the time of the research [18]; ${ }^{\ddagger}$ Averages were adjusted to represent $100 \%$ of the market.

Table 2 models the estimated daily iodine intake from instant noodles and the related percentage of RNI for iodine for each population group, according to the consumption frequency category. For respondents who reported consuming instant noodles more than once a day, this intake potentially contributed to over half (55.3\%) of the RNI for iodine for SAC, almost $44.3 \%$ of the RNI for non-pregnant WRA and just over a quarter (26.6\%) of the RNI for PW.

The median reported instant noodle intake among SAC was 3-6 packets per week (data not shown), which is estimated to meet around one quarter of the daily iodine needs for this population group. The median reported intake among both WRA and PW was 1-2 times per week, estimated to meet around 7\% (WRA) and 4\% (PW) of the daily iodine needs for these groups (Table 2).

Table 2. Estimated iodine intake from instant noodles according to consumption frequency (reported in Riskesdas 2013).

\begin{tabular}{|c|c|c|c|c|c|c|}
\hline \multirow{2}{*}{$\begin{array}{l}\text { Consumption } \\
\text { Frequency }\end{array}$} & \multirow{2}{*}{$\begin{array}{c}\text { Number of } \\
\text { Packets/Week }\end{array}$} & \multicolumn{2}{|c|}{$\begin{array}{l}\text { Estimated Iodine Intake ( } \mu \mathrm{g}) \text { from } \\
\text { Instant Noodle Consumption * }\end{array}$} & \multicolumn{3}{|c|}{$\begin{array}{l}\text { Percent Daily RNI for Iodine for Given } \\
\text { Frequency of Consumption }{ }^{+}\end{array}$} \\
\hline & & Per Week & Per Day & SAC & WRA & PW \\
\hline$>1$ time/day & 10 & 464.6 & 66.4 & $55.3 \%$ & $44.3 \%$ & $26.6 \%$ \\
\hline 1 time/day & 7 & 325.2 & 46.5 & $38.7 \%$ & $31.0 \%$ & $18.6 \%$ \\
\hline 3-6/week & 4.5 & 209.1 & 29.9 & $24.9 \%$ & $19.9 \%$ & $11.9 \%$ \\
\hline 1-2/week & 1.5 & 69.7 & 10.0 & $8.3 \%$ & $6.6 \%$ & $4.0 \%$ \\
\hline$<3 \times /$ month & 0.5 & 23.2 & 3.3 & $2.8 \%$ & $2.2 \%$ & $1.3 \%$ \\
\hline Never & 0 & 0 & 0 & $0.0 \%$ & $0.0 \%$ & $0.0 \%$ \\
\hline
\end{tabular}

RNI, recommended nutrient intake; SAC, school aged children, 10-12 years of age; WRA, non-pregnant women of reproductive age; PW, pregnant women; * Based on an average of $46.5 \mu \mathrm{g}$ iodine per packet of instant noodles;

${ }^{\dagger}$ Based on RNIs of $120 \mu \mathrm{g}, 150 \mu \mathrm{g}$ and $250 \mu \mathrm{g}$ iodine for SAC, WRA and PW, respectively [22]. 
The estimated mean and median iodine intakes from instant noodles by region and SES group for each population group are shown in Tables 3 and 4, respectively. Differences in intake are driven by differences in the frequency of consumption, since the same average iodine content per packet is used throughout. The mean estimated daily intake of iodine from the consumption of instant noodles was $23 \mu \mathrm{g} /$ day for SAC, $18.2 \mu \mathrm{g}$ /day for WRA and $16.2 \mu \mathrm{g} /$ day for PW, which is equivalent to 19.2\%, $12.1 \%$ and $6.5 \%$ of the population group-specific daily RNIs for iodine, respectively (Table 3). When the population group-specific percent RNI was based on the median intake, the percent was similar to that for the frequency of consumption $(25 \%, 7 \%$ and $4 \%$, respectively).

Table 3. Mean and median estimated intakes of iodine ( $\mu \mathrm{g} /$ day) from the consumption of instant noodles for each respondent group by geographic region.

\begin{tabular}{|c|c|c|c|c|c|c|}
\hline & \multirow{2}{*}{$N$} & \multicolumn{4}{|c|}{ Estimated Daily Iodine Intake $(\mu \mathrm{g})$ from Instant Noodles * } & \multirow{2}{*}{$\begin{array}{c}\text { Percent } \\
\text { Iodine RNI } \ddagger\end{array}$} \\
\hline & & Mean $^{\dagger}$ & $95 \%$ CI & Median & IQR & \\
\hline \multicolumn{7}{|l|}{ SAC } \\
\hline Sumatra & 506 & 21.5 & $20.1-22.8$ & 10.1 & $10.1-30.3$ & $17.9 \%$ \\
\hline Java & 1581 & 22.9 & $22.0-23.6$ & 30.3 & $10.1-30.3$ & $19.0 \%$ \\
\hline Kalimantan & 136 & 25.5 & $22.2-28.7$ & 30.3 & $10.1-47.1$ & $21.3 \%$ \\
\hline Sulawesi & 230 & 24.3 & $22.1-26.5$ & 30.3 & $10.1-30.3$ & $20.3 \%$ \\
\hline Bali-Papua & 266 & 24.1 & $21.9-26.3$ & 20.2 & $10.1-30.3$ & $20.1 \%$ \\
\hline Total & 2719 & 23.0 & $22.3-23.6$ & 30.3 & $10.1-30.3$ & $19.2 \%$ \\
\hline \multicolumn{7}{|l|}{ WRA } \\
\hline Sumatra & 2501 & $16.4^{\mathrm{a}}$ & $15.8-16.9$ & 10.1 & $10.1-30.3$ & $10.9 \%$ \\
\hline Java & 7956 & $18.2^{b}$ & $17.8-18.5$ & 10.1 & $10.1-30.3$ & $12.1 \%$ \\
\hline Kalimantan & 694 & $19.8^{c}$ & $18.5-21.0$ & 10.1 & $10.1-30.3$ & $13.2 \%$ \\
\hline Sulawesi & 899 & $19.8^{\mathrm{c}}$ & $18.7-21.0$ & 10.1 & $10.1-30.3$ & $13.2 \%$ \\
\hline Bali-Papua & 1183 & $19.6^{c}$ & $18.6-20.6$ & 10.1 & $10.1-30.3$ & $13.1 \%$ \\
\hline Total & 13,233 & 18.2 & $17.9-18.4$ & 10.1 & $10.1-30.3$ & $12.1 \%$ \\
\hline \multicolumn{7}{|l|}{ PW } \\
\hline Total & 578 & 16.2 & $15.0-17.3$ & 10.1 & $10.1-30.3$ & $6.5 \%$ \\
\hline
\end{tabular}

95\% CI, 95\% confidence interval; IQR, interquartile range; RNI, daily recommended nutrient intake; SAC, school aged children 10-12 years of age; WRA, non-pregnant women of reproductive age; PW, pregnant women; ${ }^{*}$ Based on an estimated average of $46.5 \mu \mathrm{g}$ iodine per packet of instant noodles; ${ }^{\dagger}$ Significant differences between the means (non-overlapping $95 \% \mathrm{CI}$ ) within a population group are indicated by superscript letters; $\ddagger$ Based on calculated mean iodine intakes and RNIs of $120 \mu \mathrm{g}, 150 \mu \mathrm{g}$ and $250 \mu \mathrm{g}$ iodine for SAC, WRA, and PW, respectively [22].

There was no significant difference in the mean estimated iodine intake from instant noodles by region among SAC (Table 3). However, SAC from households in the SES-2 category had higher intakes (mean $24.9 \mu \mathrm{g} /$ day; $95 \%$ CI 23.6, 26.2) than those from households in the SES-1 category (mean $21.8 \mu \mathrm{g} /$ day; 95\% CI 20.7, 22.8) (Table 4). Among WRA, the mean estimated iodine intake from instant noodles was lower in the Sumatra region (mean $16.4 \mu \mathrm{g} /$ day; 95\% CI 15.8, 16.9) than in all other regions. It was also lower in the Java region (mean $18.2 \mu \mathrm{g} /$ day; 95\% CI 17.8, 18.5) than in Kalimantan, Sulawesi and Bali-Papua (Table 3). No significant differences in iodine intake from instant noodles by household SES category were observed for WRA or for PW (Table 4).

Table 4. Mean and median estimated intakes of iodine ( $\mu \mathrm{g} /$ day) from the consumption of instant noodles according to respondent group and household SES category.

\begin{tabular}{|c|c|c|c|c|c|c|}
\hline & \multirow{2}{*}{$N$} & \multicolumn{4}{|c|}{ Estimated Daily Iodine Intake $(\mu \mathrm{g})$ from Instant Noodles * } & \multirow[t]{2}{*}{ Percent Iodine RNI $\ddagger$} \\
\hline & & Mean $^{\dagger}$ & $95 \%$ CI & Median & IQR & \\
\hline SAC & & & & & & \\
\hline SES-1 & 962 & $21.8^{\mathrm{a}}$ & $20.7-22.8$ & 10.1 & $10.1-30.3$ & $18.2 \%$ \\
\hline SES-2 & 620 & $24.9^{\mathrm{b}}$ & $23.6-26.2$ & 30.3 & $10.1-30.3$ & $20.8 \%$ \\
\hline SES-3 & 1137 & $22.9^{\mathrm{a}, \mathrm{b}}$ & $22.0-23.8$ & 30.3 & $10.1-30.3$ & $19.1 \%$ \\
\hline
\end{tabular}


Table 4. Cont.

\begin{tabular}{|c|c|c|c|c|c|c|}
\hline & \multirow{2}{*}{$N$} & \multicolumn{4}{|c|}{ Estimated Daily Iodine Intake ( $\mu \mathrm{g})$ from Instant Noodles * } & \multirow[t]{2}{*}{ Percent Iodine RNI $\ddagger$} \\
\hline & & Mean $^{+}$ & $95 \%$ CI & Median & IQR & \\
\hline \multicolumn{7}{|l|}{ WRA } \\
\hline SES-1 & 4368 & 18.4 & $17.9-18.8$ & 10.1 & $10.1-30.3$ & $12.3 \%$ \\
\hline SES-2 & 2975 & 18.5 & $17.9-19.0$ & 10.1 & $10.1-30.3$ & $12.3 \%$ \\
\hline SES-3 & 5890 & 17.9 & $17.5-18.3$ & 10.1 & $10.1-30.3$ & $11.9 \%$ \\
\hline \multicolumn{7}{|l|}{ PW } \\
\hline SES-1 & 172 & 16.5 & $14.2-18.8$ & 10.1 & $10.1-30.3$ & $6.6 \%$ \\
\hline SES-2 & 135 & 18.0 & $15.3-20.7$ & 10.1 & $10.1-30.3$ & $7.2 \%$ \\
\hline SES-3 & 271 & 15.1 & $13.5-16.7$ & 10.1 & $10.1-30.3$ & $6.0 \%$ \\
\hline
\end{tabular}

SES, socio-economic status; 95\% CI, 95\% confidence interval; IQR, interquartile range; RNI, daily recommended nutrient intake; SAC, school aged children 10-12 years of age; WRA, non-pregnant women of reproductive age; PW, pregnant women; ${ }^{*}$ Based on an estimated average of $46.5 \mu \mathrm{g}$ iodine per packet of instant noodles; ${ }^{\dagger}$ Significant differences between the means (non-overlapping $95 \% \mathrm{CI}$ ) within a population group are indicated by superscript letters; ₹ Based on calculated mean iodine intakes and RNIs of $120 \mu \mathrm{g}, 150 \mu \mathrm{g}$ and $250 \mu \mathrm{g}$ iodine for SAC, WRA, and $\mathrm{PW}$, respectively [22].

\subsection{Estimated Iodine Intake from the Consumption of Non-Packaged Drinking Water}

Table 5 shows the average non-packaged water iodine content, average consumption, and related estimated iodine intake from non-packaged water for each of the five regions for WRA, and as national estimates for SAC and PW. For WRA, the mean analysed iodine content of non-packaged drinking water was significantly lower in Sumatra $(19.6 \mu \mathrm{g} / \mathrm{L} ; 95 \%$ CI 17.2, 22.0) and Kalimantan (15.6 $\mu \mathrm{g} / \mathrm{L} ; 95 \%$ CI $12.7,18.5)$ than in Java $(24.7 \mu \mathrm{g} / \mathrm{L} ; 95 \%$ CI $22.3,27.1)$. The mean analysed content of non-packaged water by region was slightly different for SAC, since it was based on information from a different (lower) number of households. However, it followed a similar pattern of relative iodine content by region (data not shown).

For SAC, daily consumption of non-packaged drinking water ranged from $692 \mathrm{~mL} /$ day in Bali-Papua (significantly lower than in the other four regions) to $874 \mathrm{~mL} /$ day in Java (data not shown), with an overall mean consumption of $840 \mathrm{~mL} /$ day. For WRA, consumption ranged from $931 \mathrm{~mL} /$ day in Bali-Papua (significantly lower than in the other four regions) to $1104 \mathrm{~mL} /$ day in Java, with an overall mean of $1072 \mathrm{~mL} /$ day. For PW, the overall mean consumption of non-packaged drinking water was $1147 \mathrm{~mL} /$ day.

Table 5 indicates that the estimated mean iodine intake from non-packaged drinking water among SAC was $11.7 \mu \mathrm{g}$ iodine/day, equivalent to just under $10 \%$ of the RNI for iodine for this population group. The estimated mean iodine intake from non-packaged drinking water for both WRA and PW was $16.7 \mu \mathrm{g} /$ day, equivalent to $11.1 \%$ of the RNI for iodine for WRA and $6.7 \%$ of the RNI for PW.

The estimated daily iodine intake from non-packaged drinking water varied by region for WRA. The estimated iodine intake from water in Bali-Papua was significantly lower (mean $9.7 \mu \mathrm{g} / \mathrm{day}$; $95 \%$ CI 9.0, 10.5) than in other regions, while iodine intake from non-packaged drinking water was significantly higher in Java (mean $16.5 \mu \mathrm{g} /$ day; $95 \%$ CI 16.0, 17.0) than in other regions.

Table 6 shows no significant differences in the mean iodine intake from non-packaged drinking water by household SES category among SAC or PW. However, iodine intake from non-packaged drinking water increased significantly with household SES category among WRA, from $13.7 \mu \mathrm{g}$ iodine/day (95\% CI 13.4, 14.0) for SES-1 households to $17.1 \mu \mathrm{g}$ iodine/day $(95 \%$ CI $16.5,17.7)$ for SES-3 households.

\subsection{Estimated Iodine Intake from Salt Consumption}

The findings for the iodine content of household salt (Table 7) for SAC and WRA showed a fairly consistent pattern by region. A significantly higher mean household salt iodine content was found in the Kalimantan region for SAC $(30.2 \mathrm{mg} / \mathrm{kg} ; 95 \%$ CI $26.5,34.0)$ and WRA $(27.3 \mathrm{mg} / \mathrm{kg}$; $95 \%$ CI 25.7 , 28.9) than for other regions. The mean household salt iodine content was lowest in the Sumatra region 
for SAC (16.6 mg/kg; 95\% CI 14.9, 18.2) and WRA (16.5 mg/kg; 95\% CI 16.0, 17.1). Among SAC, the difference was significant when compared with the levels in Kalimantan and Java. Among WRA, the level was significantly lower than in all other regions.

The reported household salt consumption data resulted in average salt intakes which were fairly comparable between regions. Higher intakes were reported among WRA and PW (mean salt intake 3.7 and $3.6 \mathrm{~g} /$ day, respectively, for the national sample) than among SAC (mean salt intake $3.0 \mathrm{~g} /$ day for the national sample).

Estimated iodine intake and the percentage of the RNI for iodine from household salt showed the same regional trends as for salt iodine content for SAC and WRA. The intake of iodine from household salt was significantly higher in the Kalimantan region $(93.1 \mathrm{mg} / \mathrm{kg}$; 95\% CI 82.6, 103.6 for SAC and $100.2 \mathrm{mg} / \mathrm{kg}$; 95\% CI 95.0, 105.4 for WRA) than in all other regions (except for Sulawesi for WRA). Household salt iodine in this region potentially accounted for $77.6 \%$ of the iodine RNI for SAC and $66.8 \%$ of the RNI for WRA. The lowest contributions to dietary intake of iodine through household salt were found in Sumatra, where it accounted for approximately 37\% of the RNI for both SAC and WRA.

Overall, household salt iodine was estimated to have provided approximately half of the RNI for iodine in the national sample of SAC (48.8\% of the RNI) and WRA (47.6\%) and just over a quarter of the RNI for the national sample of PW (28.0\% of the RNI).

Table 8 shows that estimated salt consumption was similar between household SES categories for each population group. The iodine content of household salt was, however, found to be 2.4 to $5.8 \mathrm{mg} / \mathrm{kg}$ lower for SES-1 households than for SES-3 households-a significant difference for each population group. This resulted in significantly lower iodine intakes from household salt for all three population groups in the lowest SES category households when compared with the same group in the highest SES category households. The percentages of the iodine RNI consumed in household salt for households in the SES-1 category were $44.5 \%$ for SES-1 and 52.4\% for SES-3 for SAC; compared with households in the SES-3 category, which showed percentages of $44.1 \%$ and $49.8 \%$ for WRA, and $23.1 \%$ and $29.8 \%$ for PW. 
Table 5. Mean and median iodine contents of non-packaged drinking water ( $\mu \mathrm{g} / \mathrm{L})$ and estimated daily iodine intakes and percentages of RNI from non-packaged drinking water by region.

\begin{tabular}{|c|c|c|c|c|c|c|c|c|c|c|c|c|}
\hline & \multirow{2}{*}{$N$} & \multicolumn{4}{|c|}{$\begin{array}{l}\text { Analysed Iodine Content }(\mu \mathrm{g} / \mathrm{L}) \text { of } \\
\text { Non-Packaged Drinking Water }\end{array}$} & \multirow{2}{*}{$N$} & \multirow{2}{*}{$\begin{array}{c}\text { Average Water } \\
\text { Consumption (mL/day) }\end{array}$} & \multicolumn{4}{|c|}{$\begin{array}{l}\text { Estimated Daily Iodine Intake ( } \mu \mathrm{g}) \text { from } \\
\text { Non-Packaged Drinking Water }\end{array}$} & \multirow{2}{*}{$\begin{array}{c}\text { Percent } \\
\text { Iodine RNI }^{+}\end{array}$} \\
\hline & & Mean * & $95 \% \mathrm{CI}$ & Median & IQR & & & Mean * & $95 \%$ CI & Median & IQR & \\
\hline $\begin{array}{l}\text { SAC } \\
\text { Total }\end{array}$ & 484 & 19.5 & $17.6-21.4$ & 15.0 & $0-30$ & 2719 & 840 & 11.7 & $11.3-12.0$ & 10.6 & $10-12.6$ & $9.7 \%$ \\
\hline WRA & & & & & & & & & & & & \\
\hline Sumatra & 365 & $19.6^{\mathrm{a}}$ & $17.2-22.0$ & 16.0 & $2-27$ & 2501 & 1051 & $15.3^{\mathrm{a}}$ & $14.9-15.8$ & 13.5 & $9.5-16.1$ & $10.2 \%$ \\
\hline Java & 1258 & $24.7^{\mathrm{b}}$ & 22.3-27.1 & 15.0 & $2-30$ & 7956 & 1104 & $16.5^{\mathrm{b}}$ & $16.0-17.0$ & 12.6 & $12.6-14.9$ & $11.0 \%$ \\
\hline Kalimantan & 105 & $15.6^{\mathrm{a}}$ & $12.7-18.5$ & 14.0 & $0-27$ & 694 & 1033 & $15.1^{\mathrm{a}}$ & $14.5-15.6$ & 17.1 & 7.9-18.5 & $10.0 \%$ \\
\hline Sulawesi & 129 & $21.2^{a, b}$ & $17.4-25.0$ & 16.0 & $0-35$ & 899 & 1062 & $15.3^{\mathrm{a}}$ & $14.7-16.0$ & 13.9 & $11.8-18.2$ & $10.2 \%$ \\
\hline Bali-Papua & 206 & $19.6^{a, b}$ & $16.2-23.0$ & 12.0 & $0-32$ & 1183 & 931 & $9.7^{\mathrm{c}}$ & $9.0-10.5$ & 6.6 & $0-16.4$ & $6.5 \%$ \\
\hline Total & 2063 & 22.6 & $21.0-24.2$ & 15.0 & $0-30$ & 13,233 & 1072 & 16.7 & $15.2-15.8$ & 13.2 & $12.6-16.3$ & $11.1 \%$ \\
\hline $\mathrm{PW}$ & & & & & & & & & & & & \\
\hline Total & 213 & 17.3 & $14.5-20.1$ & 12.0 & $0-26$ & 578 & 1147 & 16.7 & $15.4-18.0$ & 13.2 & $10.8-18.3$ & $6.7 \%$ \\
\hline
\end{tabular}

95\% CI, 95\% confidence interval; IQR, interquartile range; RNI, daily recommended nutrient intake; SAC, school aged children, 10-12 years of age; WRA, non-pregnant women of reproductive age; PW, pregnant women; ${ }^{*}$ Significant differences between the means (non-overlapping $95 \% \mathrm{CI}$ ) within a population group are indicated by superscript letters; ${ }^{\dagger}$ Based on calculated mean iodine intakes and RNIs of $120 \mu \mathrm{g}, 150 \mu \mathrm{g}$ and $250 \mu \mathrm{g}$ iodine for SAC, WRA, and PW, respectively [22].

Table 6. Mean and median iodine contents of non-packaged drinking water ( $\mu \mathrm{g} / \mathrm{L})$ and estimated daily iodine intakes $(\mu \mathrm{g})$ and percentages of RNI from non-packaged drinking water by household SES category.

\begin{tabular}{|c|c|c|c|c|c|c|c|c|c|c|c|c|}
\hline & \multirow[t]{2}{*}{$N$} & \multicolumn{4}{|c|}{$\begin{array}{l}\text { Analysed Iodine Content }(\mu \mathrm{g} / \mathrm{L}) \text { of } \\
\text { Non-Packaged Drinking Water }\end{array}$} & \multirow[t]{2}{*}{$N$} & \multirow[t]{2}{*}{$\begin{array}{c}\text { Average Water } \\
\text { Consumption (mL/day) }\end{array}$} & \multicolumn{4}{|c|}{$\begin{array}{l}\text { Estimated Daily Iodine Intake ( } \mu \mathrm{g}) \text { from } \\
\text { Non-Packaged Drinking Water }\end{array}$} & \multirow{2}{*}{$\begin{array}{l}\text { Percent Iodine } \\
\text { RNI }^{\dagger}\end{array}$} \\
\hline & & Mean * & $95 \% \mathrm{CI}$ & Median & IQR & & & Mean * & $95 \% \mathrm{CI}$ & Median & IQR & \\
\hline \multicolumn{13}{|l|}{ SAC } \\
\hline SES-1 & 159 & 23.4 & $19.7-21.2$ & 19 & 5-32 & 962 & 823 & 11.4 & $10.8-12.0$ & 10.6 & $10-11.8$ & $9.5 \%$ \\
\hline SES-2 & 117 & 17.3 & $13.9-20.7$ & 13 & $0-28$ & 620 & 842 & 11.6 & $11.0-12.2$ & 10.6 & $10-12.6$ & $9.7 \%$ \\
\hline SES-3 & 208 & 17.7 & $15.0-20.5$ & 12 & $0-27.5$ & 1137 & 853 & 11.9 & $11.4-12.4$ & 10.6 & $9.8-12.9$ & $9.9 \%$ \\
\hline \multicolumn{13}{|l|}{ WRA } \\
\hline SES-1 & 602 & $18.9^{\mathrm{a}}$ & $17.1-20.7$ & 14 & $0-29$ & 4368 & 1052 & $13.7^{\mathrm{a}}$ & $13.4-14.0$ & 12.6 & $12.6-15.9$ & $9.1 \%$ \\
\hline SES-2 & 468 & $21.1^{\mathrm{a}, \mathrm{b}}$ & $17.6-24.6$ & 14 & $0-28$ & 2975 & 1069 & $15.1^{\mathrm{b}}$ & $14.5-15.7$ & 12.6 & $12.6-16.1$ & $10.1 \%$ \\
\hline SES-3 & 993 & $25.6^{\mathrm{a}}$ & $23.0-28.3$ & 16 & $1-31$ & 5890 & 1089 & $17.1^{\mathrm{c}}$ & $16.5-17.7$ & 13.9 & $12.6-16.9$ & $11.4 \%$ \\
\hline \multicolumn{13}{|l|}{ PW } \\
\hline SES-1 & 60 & 19.6 & $14.3-24.9$ & 18 & $0-27$ & 172 & 1114 & 17.0 & $14.6-19.3$ & 13.2 & $11.8-19.4$ & $6.8 \%$ \\
\hline SES-2 & 49 & 20.2 & $13.0-27.4$ & 10 & $0-38$ & 135 & 1122 & 17.3 & $14.1-20.5$ & 13.2 & $10.8-17.5$ & $6.9 \%$ \\
\hline SES-3 & 104 & 14.7 & $11.1-18.2$ & 11 & $0-22.5$ & 271 & 1181 & 16.3 & $14.5-18.0$ & 13.2 & $10.8-18.3$ & $6.5 \%$ \\
\hline
\end{tabular}

SES, socio-economic status; $95 \%$ CI, 95\% confidence interval; IQR, interquartile range; RNI, daily recommended nutrient intake; SAC, school aged children 10-12 years of age; WRA, non-pregnant women of reproductive age; PW, pregnant women; * Significant differences between the means (non-overlapping $95 \% \mathrm{CI}$ ) within a population group are indicated by superscript letters; ${ }^{\dagger}$ Based on calculated mean iodine intakes and RNIs of $120 \mu \mathrm{g}, 150 \mu \mathrm{g}$ and $250 \mu \mathrm{g}$ iodine for SAC, WRA, and PW, respectively [22]. 
Table 7. Mean and median iodine contents of household salt $(\mathrm{mg} / \mathrm{kg})$ and estimated daily iodine intakes ( $\mu \mathrm{g})$ and percentages of RNI from household salt by region.

\begin{tabular}{|c|c|c|c|c|c|c|c|c|c|c|c|c|}
\hline & \multirow{2}{*}{$N$} & \multicolumn{4}{|c|}{ Analysed Iodine Content $(\mathrm{mg} / \mathrm{kg})$ of Household Salt } & \multirow[t]{2}{*}{$N$} & \multirow[t]{2}{*}{$\begin{array}{l}\text { Average Household Salt } \\
\text { Consumption (g/day) }\end{array}$} & \multicolumn{4}{|c|}{$\begin{array}{c}\text { Estimated Daily Iodine Intake ( } \mu \mathrm{g}) \text { from } \\
\text { Household Salt }\end{array}$} & \multirow[t]{2}{*}{$\begin{array}{l}\text { Percent Iodine } \\
\text { RNI }^{\dagger}\end{array}$} \\
\hline & & Mean* & $95 \% \mathrm{CI}$ & Median & IQR & & & Mean * & $95 \% \mathrm{CI}$ & Median & IQR & \\
\hline \multicolumn{13}{|l|}{ SAC } \\
\hline Sumatra & 413 & $16.6^{\mathrm{a}}$ & $14.9-18.2$ & 13.0 & $7.4-21.2$ & 506 & 2.8 & $44.3^{\mathrm{a}}$ & $40.7-47.8$ & 35.8 & $21.5-52.2$ & $36.9 \%$ \\
\hline Java & 1341 & $20.6^{\mathrm{b}}$ & $19.8-21.4$ & 16.9 & $10.6-26.5$ & 1581 & 3.2 & $64.7^{\mathrm{b}}$ & $62.5-66.9$ & 55.8 & $35.4-81.3$ & $53.9 \%$ \\
\hline Kalimantan & 115 & $30.2^{\mathrm{c}}$ & $26.5-34.0$ & 24.3 & $15.9-39.1$ & 136 & 3.1 & $93.1^{\mathrm{c}}$ & $82.6-103.6$ & 80.4 & $54.4-118.5$ & $77.6 \%$ \\
\hline Sulawesi & 185 & $18.9^{\mathrm{a}, \mathrm{b}}$ & $17.0-20.9$ & 15.9 & $9.5-24.8$ & 230 & 2.7 & $45.8^{\mathrm{a}}$ & $42.1-49.5$ & 36.1 & $29.5-58.4$ & $38.1 \%$ \\
\hline Bali-Papua & 235 & $18.6^{\mathrm{a}, \mathrm{b}}$ & $16.5-20.7$ & 13.8 & $5.3-26.5$ & 266 & 2.6 & $43.3^{\mathrm{a}}$ & $39.0-47.6$ & 31.8 & $17.7-54.7$ & $36.1 \%$ \\
\hline Total & 2289 & 20.0 & $19.4-20.7$ & 15.9 & $9.5-26.5$ & 2719 & 3.0 & 58.6 & $56.9-60.3$ & 49.3 & $30.5-74$ & $48.8 \%$ \\
\hline \multicolumn{13}{|l|}{ WRA } \\
\hline Sumatra & 2067 & $16.5^{\mathrm{a}}$ & $16.0-17.1$ & 13.8 & $8.5-21.2$ & 2501 & 3.5 & $55.5^{\mathrm{a}}$ & $53.9-57.1$ & 47.0 & $29.4-67.4$ & $37.0 \%$ \\
\hline Java & 6773 & $20.6^{b}$ & $20.3-21.0$ & 16.9 & $9.5-27.5$ & 7956 & 3.8 & $77.0^{\mathrm{b}}$ & $75.8-78.2$ & 69.0 & $40.8-98.7$ & $51.4 \%$ \\
\hline Kalimantan & 595 & $27.3^{c}$ & $25.7-28.9$ & 22.2 & $14.8-33.9$ & 694 & 3.7 & $100.2^{\mathrm{c}}$ & $95.0-105.4$ & 83.6 & $57.4-117.6$ & $66.8 \%$ \\
\hline Sulawesi & 696 & $19.0^{\mathrm{b}}$ & $18.0-20.0$ & 15.9 & $9.2-26.2$ & 899 & 3.3 & $57.0^{\mathrm{ac}}$ & $54.6-59.4$ & 45.8 & $36.5-72.1$ & $38.0 \%$ \\
\hline Bali-Papua & 1044 & $20.5^{\mathrm{b}}$ & $19.4-21.6$ & 15.9 & $6.3-28.6$ & 1183 & 3.4 & $62.0^{\mathrm{c}}$ & $59.0-65.0$ & 44.8 & $27-81.3$ & $41.3 \%$ \\
\hline $\begin{array}{l}\text { Total } \\
\text { PW }\end{array}$ & 11,175 & 20.1 & $19.8-20.4$ & 15.9 & $9.2-26.5$ & 13,233 & 3.7 & 71.5 & $70.6-72.4$ & 59.2 & $37.5-90.1$ & $47.6 \%$ \\
\hline Total & 484 & 20.4 & $19.0-21.8$ & 15.9 & $9.2-28.6$ & 578 & 3.6 & 70.0 & $65.7-74.3$ & 59.0 & 31.9-92 & $28.0 \%$ \\
\hline
\end{tabular}

$95 \%$ CI, 95\% confidence interval; IQR, interquartile range; RNI, daily recommended nutrient intake; SAC, School aged children 10-12 years of age; WRA, non-pregnant women of reproductive age; PW, pregnant women; ${ }^{*}$ Significant differences between the means (non-overlapping $95 \% \mathrm{CI}$ ) within a population group are indicated by superscript letters; ${ }^{\dagger}$ Based on calculated mean iodine intakes and RNIs of $120 \mu \mathrm{g}, 150 \mu \mathrm{g}$ and $250 \mu \mathrm{g}$ iodine for SAC, WRA, and PW, respectively [22]. 
Table 8. Mean and median iodine contents of household salt ( $\mathrm{mg} / \mathrm{kg}$ ) and estimated daily iodine intakes ( $\mu \mathrm{g})$ and percentages of RNI from household salt by household SES category.

\begin{tabular}{|c|c|c|c|c|c|c|c|c|c|c|c|c|}
\hline & \multirow[t]{2}{*}{$N$} & \multicolumn{4}{|c|}{ Analysed Iodine Content (mg/kg) of Household Salt } & \multirow[t]{2}{*}{$N$} & \multirow[t]{2}{*}{$\begin{array}{l}\text { Average Household Salt } \\
\text { Consumption (g/day) }\end{array}$} & \multicolumn{4}{|c|}{$\begin{array}{c}\text { Estimated Daily Iodine Intake }(\mu \mathrm{g}) \text { from } \\
\text { Household Salt }\end{array}$} & \multirow[t]{2}{*}{$\begin{array}{c}\text { Percent Iodine } \\
\text { RNI }^{\dagger}\end{array}$} \\
\hline & & Mean * & $95 \% \mathrm{CI}$ & Median & IQR & & & Mean * & $95 \%$ CI & Median & IQR & \\
\hline \multicolumn{13}{|l|}{ SAC } \\
\hline SES-1 & 796 & $18.4^{\mathrm{a}}$ & $17.3-19.5$ & 14.1 & $7.4-24.3$ & 962 & 3.0 & $53.5^{\mathrm{a}}$ & $50.8-56.1$ & 45.9 & $26.4-67.6$ & $44.5 \%$ \\
\hline SES-2 & 520 & $19.7^{\mathrm{a}, \mathrm{b}}$ & $18.4-20.9$ & 15.9 & $9.5-26.5$ & 620 & 3.1 & $58.7^{\mathrm{a}, \mathrm{b}}$ & $55.4-61.9$ & 50.8 & $31-75.3$ & $48.9 \%$ \\
\hline SES-3 & 973 & $21.5^{\mathrm{b}}$ & $20.4-22.6$ & 18.0 & $10.6-28.6$ & 1137 & 3.1 & $62.9^{\mathrm{b}}$ & $60.1-65.8$ & 50.9 & $33-80.6$ & $52.4 \%$ \\
\hline \multicolumn{13}{|l|}{ WRA } \\
\hline SES-1 & 3683 & $18.7^{\mathrm{a}}$ & $18.2-19.2$ & 14.8 & $7.4-25.3$ & 4368 & 3.7 & $66.1^{\mathrm{a}}$ & $64.6-67.6$ & 56.6 & $32.8-81.7$ & $44.1 \%$ \\
\hline SES-2 & 2482 & $20.3^{b}$ & $19.7-20.9$ & 16.7 & $9.2-26.5$ & 2975 & 3.7 & $73.0^{\mathrm{b}}$ & $71.1-75.0$ & 60.8 & $38.4-91.9$ & $48.7 \%$ \\
\hline SES-3 & 5010 & $21.1^{\mathrm{b}}$ & $20.7-21.5$ & 18.0 & $10.6-27.5$ & 5890 & 3.7 & $74.7^{\mathrm{b}}$ & $73.3-76.0$ & 60.8 & $39.7-96.6$ & $49.8 \%$ \\
\hline \multicolumn{13}{|l|}{ PW } \\
\hline SES-1 & 142 & $16.1^{\mathrm{a}}$ & $14.1-18.0$ & 13.9 & $6.3-21.2$ & 172 & 3.6 & $57.8^{a}$ & $51.1-64.5$ & 48.7 & $24-78.9$ & $23.1 \%$ \\
\hline SES-2 & 107 & $22.9^{b}$ & $19.4-26.4$ & 20.1 & $10.6-29.6$ & 135 & 3.6 & $76.2^{b}$ & $66.5-86.0$ & 67.5 & $35.7-93.3$ & $30.5 \%$ \\
\hline SES-3 & 235 & $21.9^{b}$ & $19.8-23.9$ & 16.9 & $9.5-31.7$ & 271 & 3.5 & $74.6^{b}$ & $68.2-80.9$ & 59.7 & $35.4-99.4$ & $29.8 \%$ \\
\hline
\end{tabular}

SES, socio-economic status; 95\% CI, 95\% confidence interval; IQR, interquartile range; RNI, daily recommended nutrient intake; SAC, school aged children 10-12 years of age; WRA, non-pregnant women of reproductive age; PW, pregnant women; * Significant differences between the means (non-overlapping $95 \% \mathrm{CI}$ ) within a population group are indicated by superscript letters; ${ }^{\dagger}$ Based on calculated mean iodine intakes and RNIs of $120 \mu \mathrm{g}, 150 \mu \mathrm{g}$ and $250 \mu \mathrm{g}$ iodine for SAC, WRA, and PW, respectively [22]. 


\subsection{Estimated Iodine Intake from the Three Sources Combined}

Estimates of combined iodine intake from each of the three products above-instant noodles, non-packaged drinking water, and household salt-were calculated for each sub-group to estimate the potential combined contribution to the iodine RNI. Figure 1 illustrate the total combined contribution with an indication of individual source contributions for each population group by region and by household SES category.

For all groups, iodine from household salt can be seen to be the most important of the three sources contributing to dietary iodine intake; this source also shows the most variation between sub-groups.

The total estimated iodine intake from these three sources accounted for 63\% (Bali-Papua region) to $109 \%$ (Kalimantan region) of the iodine RNI for SAC, and 58\% (Sumatra region) to $90 \%$ (Kalimantan region), of the iodine RNI for WRA (Figure 1). The second highest regional iodine intakes from these three sources (after Kalimantan) were found in the Java region, accounting for approximately $83 \%$ of the iodine RNI for SAC and 75\% of the RNI for WRA. The estimated combined contributions to the iodine RNI were approximately the same- $58-68 \%$ of the RNI-for the remaining three regions for both SAC and WRA.

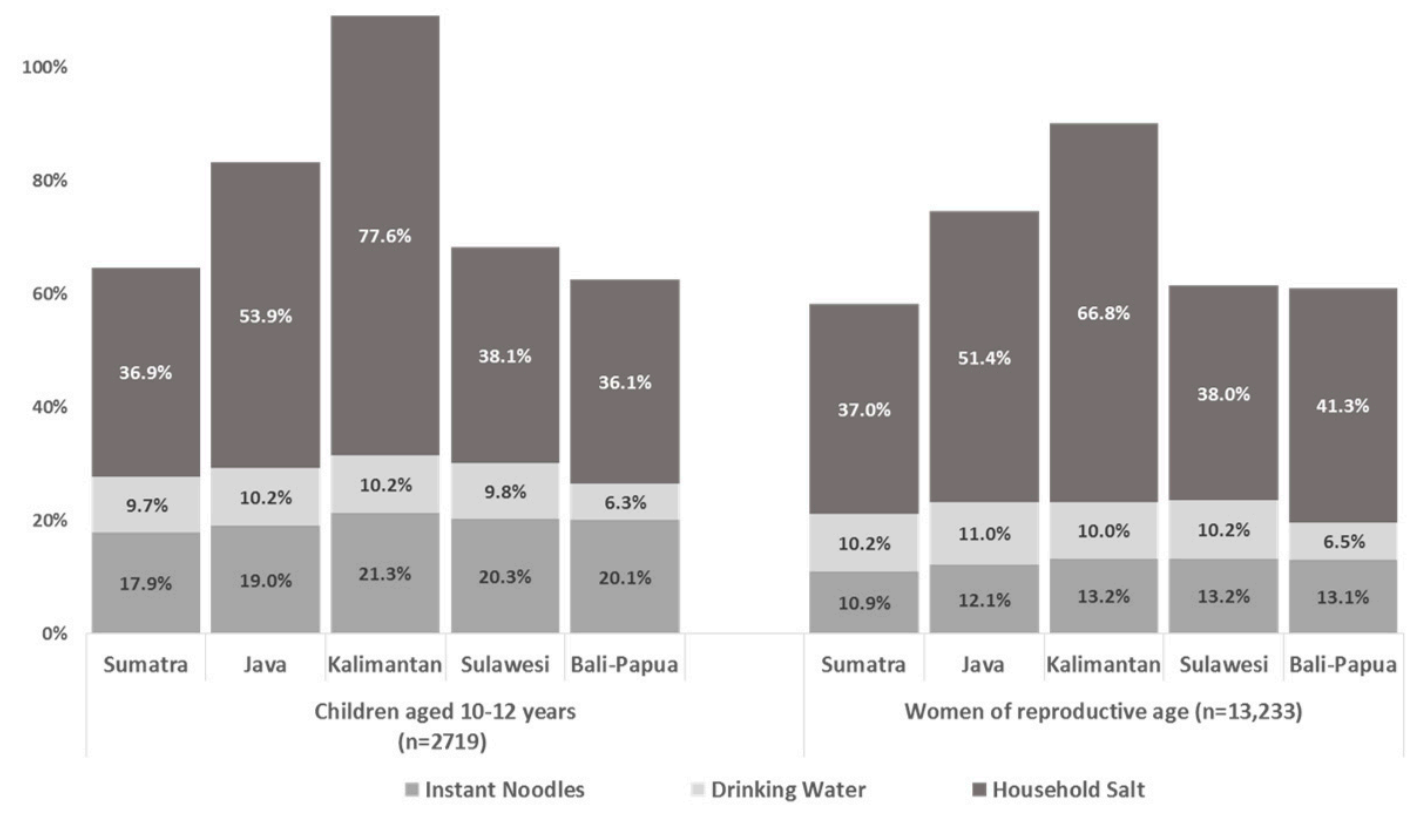

Figure 1. Estimates for the percent contributions to the iodine recommended nutrient intake (RNI) from iodised salt in instant noodles, household salt iodine and from trace iodine in non-packaged drinking water, according to respondent group and region.

Figure 2 indicates that, among SAC and WRA, consumption of these three products has an increasing contribution to iodine intake as household SES increases. The potential contribution to the iodine RNI changed from $72.2 \%$ among SAC from households in the SES- 1 category to $81.5 \%$ among SAC from households in the SES-3 category. A similar increase, from 65.4 to $73.1 \%$ of the iodine RNI, was seen among WRA from households in the SES-1 and SES-3 categories. A similar but less pronounced increase in iodine intake from these three sources was seen among PW, increasing from 36.5 (SES-1) to $42-45 \%$ (SES-2 and 3) of the estimated contribution to the iodine RNI.

Figure 2 also shows the estimated total iodine intake and contribution to the iodine RNI for instant noodles, non-packaged drinking water and household salt on a national level. These were estimated to be $93.2 \mu \mathrm{g} /$ day and $77.7 \%$ of the iodine RNI for SAC; $105.2 \mu \mathrm{g} /$ day and $70.1 \%$ of the RNI for WRA; and $102.9 \mu \mathrm{g} /$ day and $41.2 \%$ of the RNI for PW. 


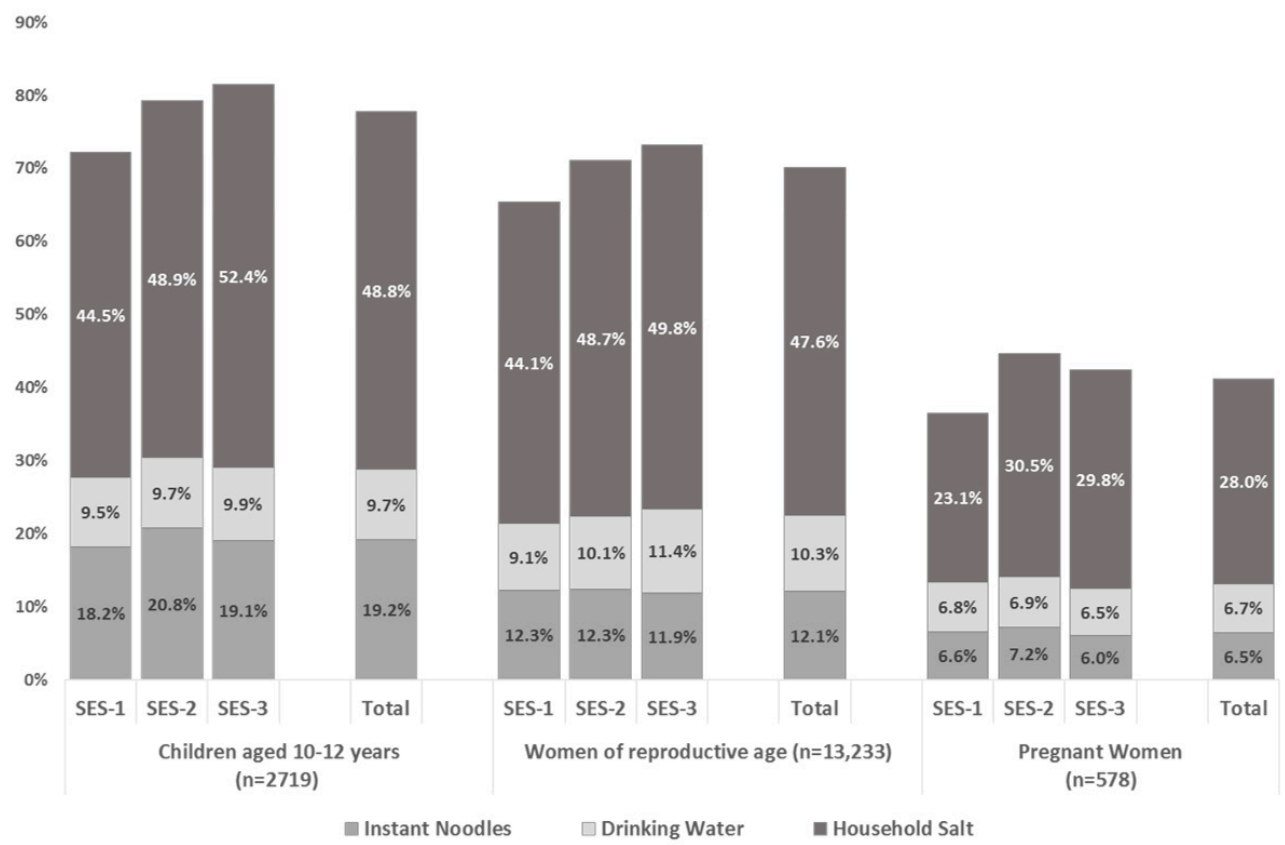

Figure 2. Estimates for the percent contribution to the iodine recommended nutrient intake (RNI) from iodised salt in instant noodles, household salt iodine and from trace iodine in non-packaged drinking water, according to respondent group and household socio-economic status (SES). SES-1 indicates the lowest status, SES-3 indicates the highest status. The estimates are based on iodine RNIs of $120 \mu \mathrm{g}$, $150 \mu \mathrm{g}$ and $250 \mu \mathrm{g}$ for SAC, WRA, and PW, respectively [22].

\section{Discussion}

This study shows that, on a national level in Indonesia, iodine intake from iodine added to household salt, together with iodine added to salt used in the production of instant noodles and the naturally occurring iodine from non-packaged drinking water, meets around three quarters of the iodine requirements for SAC and WRA, and around two fifths of requirements among PW. PW had the lower percentage of iodine RNI met by all sources, due, at least partially, to the higher recommended requirement for this group. On a sub-national level, these three dietary sources met over half the iodine RNI for SAC and WRA in all five regions.

Of the three sources, iodine from household salt consumption provided the greatest relative contribution to iodine intake among all respondent groups. These data suggest that without iodisation of salt in the household and food industry (in this case instant noodles), dietary intake of iodine may be below the RNI across all population groups. Additional studies of other (non-salt, non-water) sources of dietary iodine, combined with an assessment of the relationship between urinary sodium and urinary iodine are needed to fully determine this.

The assumptions used for the estimation of the iodine content of instant noodles in this paper were conservative in terms of salt iodine level and industry practices regarding iodised salt. Evidence generated since the time of the survey and data analysis indicate that the Wings group now use iodised salt in the production of Mi Sedap instant noodles [25]. If all other assumptions remain the same, the consideration that Wings noodles use iodised salt would increase the average iodine content per packet of instant noodles from $46.5 \mu \mathrm{g}$ to $56.5 \mu \mathrm{g}$. This increases the relative contribution to dietary iodine from this source by about $20 \%$ of its current amount.

The estimated average consumption of salt from various food sources reported from the 2014 SKMI is $6.8 \mathrm{~g} /$ day for SAC, WRA and PW. This is higher than the Indonesian Ministry of Health recommended intake of $3.7 \mathrm{~g}$ salt/day (based on a recommended intake of sodium of not more than $1500 \mathrm{mg}$ per day) [26] and the WHO recommended intake of $5 \mathrm{~g} /$ day. The estimated contributions of household salt to this total salt consumption are $44 \%, 54 \%$ and $52 \%$ for SAC, WRA and PW, 
respectively [19]. Current regulatory guidelines for salt iodisation in Indonesia are only enforced for household salt. If all salt for human consumption was iodised to $18 \mathrm{mg} / \mathrm{kg}$, then consuming $6.8 \mathrm{~g}$ of salt a day from household and food industry sources of salt could provide $122 \mu \mathrm{g}$ dietary iodine. This would meet approximately $100 \%, 80 \%$ and $50 \%$ of the recommended iodine requirements for SAC, WRA and PW, respectively. The additional estimated 12-13 $\mu$ g iodine from non-packaged drinking water would maintain the iodine intakes within an optimal level for SAC and reach over $90 \%$ and $60 \%$ of dietary needs for WRA and PW, respectively.

Differences in dietary behaviour between the three population groups meant that the intake of iodine from instant noodles was almost double that estimated from non-packaged drinking water among SAC. Among WRA and PW, the relative contributions to dietary iodine from instant noodles and non-packaged drinking water were similar.

In general, the degree to which food industry (iodised) salt contributes to total dietary salt and related iodine intake would be expected to vary within Indonesia. These variations occur according to the national food industry structure and practices of using iodised salt, food distribution and population access to markets, and regional differences in dietary practices. Ensuring regulation for both the use of, and expected acceptable range for, iodised salt in the food industry will help standardise iodine intake regardless of dietary sources of salt.

Current national standards for salt iodisation in Indonesia do not include an upper level of iodisation. This should be reconsidered based on these data, which suggest the average iodine content for household salt in Kalimantan, for example, took total iodine intake to levels above requirements for SAC in this region (a region which accounts for only $6 \%$ of the total population). In the meantime, regulatory monitoring of the household salt supply should be strengthened, focused initially on the supply to the Kalimantan and Sumatra regions and to areas of lower SES, where results suggest that the salt supply may have been inadequately iodised.

Enforced iodisation of all sources of edible salt, combined with monitoring iodine status among different population groups will inform and facilitate future adjustments in salt iodine standards. This has particular relevance to salt reduction initiatives which can and should be implemented in a complementary manner with USI [27].

The quantity of non-packaged drinking water consumed and its iodine content were both highly variable. The range of iodine levels in non-packaged drinking water was found to be 0 to $439 \mu \mathrm{g} / \mathrm{L}$, with a median of $17 \mu \mathrm{g} / \mathrm{L}$ in urban areas and $13 \mu \mathrm{g} / \mathrm{L}$ in rural areas, nationally [8]. It would not be feasible or recommended to adjust salt iodisation standards at the sub-national level to account for these variations. It is, however, helpful to have an idea of the degree of variation, which may, in some cases, help to explain notable discrepancies between iodine status and access to iodised household and processed food salt.

The limitations of this study were mainly due to constraints regarding the available data from the SKMI dataset. The fact that it was not possible to link households between surveys meant it was necessary to apply regional estimates for non-packaged drinking water and household salt to households in a region. In addition, the exact proportion of sodium from salt in the instant noodles could not be verified; however, it was assumed that the amount from preservatives and sodium-containing flavour enhancers was a small proportion of the total. The design, methodological concept and results are, however, valuable as this is the first investigation of this kind in Indonesia.

\section{Conclusions}

The results presented in this paper show that using household coverage of adequately iodised salt as an indicator of progress towards USI and optimal iodine nutrition in Indonesia currently captures the major dietary source of iodine. However, these data and the background referenced literature make it clear that household salt iodine content and coverage cannot be used as the only indicators of total iodine intake from iodised salt sources, or as a reliable proxy for expected iodine status. Household salt does not account for all dietary sources of (potentially iodised) salt, especially among SAC and 
among the population in lower SES households. These data add to a body of evidence supporting the development of additional programme guidance to better advocate for iodisation of all edible salt, including in processed foods and condiments, with associated regulations and monitoring [28-30].

It is clear that iodisation of all edible salt will provide iodine through a variety of dietary sources, ensuring more equitable protection from inadequate iodine intake. Iodisation in the food industry as well as in household salt is particularly important for those living in areas without access to adequately iodised household salt and for population groups consuming an increasing proportion of dietary salt from processed foods rather than from household salt [12,31].

This study also provides answers to a long-standing question about the variation in ground water iodine levels in Indonesia and the influence this may have on iodine status. The estimated contribution of non-packaged drinking water iodine to the regional average for iodine intake, while widely variable, did not reach higher than $11 \%$ of the RNI for iodine for any sub-group. This would therefore not be expected to have a major impact on population iodine status when compared with that from USI.

Acknowledgments: The authors would like to thank Jonathan Gorstein for his review of the design concept and final paper, Bimo, Sri Sukotjo and Soekirman for his programmatic contributions that made this paper possible, Greg S. Garrett for reviewing the paper. Financial Support: This work was supported by The Government of Indonesia; and The Bill \& Melinda Gates Foundation (BMGF) grant number 48965 (GAIN). BMGF had no role in the design, analysis or writing of this article. Ethical Approval: The Riskesdas 2013 and SKMI 2014 were approved by the ethical board from National Institute for Health Research and Development Ministry of Health Indonesia (registration numbers LB.02.01/5.2/KE.006/2013 and LB.02.01/5.2/KE.189/2014). All data were anonymous at the time of analysis.

Author Contributions: A.Sut. and J.K. designed the analysis, A.B. provided oversight for the data collection, A.Sut. and A.B. conducted the data analysis, J.K. and A.Sut. wrote the manuscript, with contributions from A.Sug. and R.M. All authors, reviewed, edited, and approved the final manuscript.

Conflicts of Interest: The authors declare no conflict of interest.

\section{References}

1. Zimmermann, M.B.; Jooste, P.L.; Pandav, C.S. Iodine deficiency disorders. Lancet 2008, 372, 1251-1262. [CrossRef]

2. Delange, F. Iodine deficiency as a cause of brain damage. Postgrad. Med. J. 2001, 77, 217-220. [CrossRef] [PubMed]

3. Ma, Z.F.; Skeaff, S.A. Assessment of population iodine status. In Iodine Deficiency Disorders and Their 490 Elimination; Pearce, E.N., Ed.; Springer: Cham, Switzerland, 2017; pp. 15-28.

4. WHO Secretariat; Andersson, M.; de Benoist, B.; Delange, F.; Zupan, J. Prevention and control of iodine deficiency in pregnant and lactating women and in children less than 2-years-old: Conclusions and recommendations of the Technical Consultation. Public Health Nutr. 2007, 10, 1606-1611.

5. Goh, C. An Analysis of Combating Iodine Deficiency: Case Studies of China, Indonesia and Madagascar; World Bank Working Paper; World Bank: Washington, DC, USA, 2001.

6. Keputusan Presiden Republik Indonesia, Nomor 69 Tahun 1994, Tentang, Pengadaan Garam Beryodium. 1994. Available online: http://www.pom.go.id/pom/garam/KEPUTUSAN_PRESIDEN_REPUBLIK_ INDONESIA.htm (accessed on 17 April 2017).

7. Badan Standarisasi Nasional; Indonesian National Standards (SNI) for Iodized Edible (Table) Salt; SNI 3556:2010. 2010. Available online: http://registrasipangan.pom.go.id/assets/uploads/files/referensi/ 2ee62-sni-3556-2010-garam-konsumsi-beryodium.pdf (accessed on 17 April 2017).

8. National Institute for Health Research and Development. Laporan Riset Kesehatan Dasar Indonesia; National Institute for Health Research and Development: Jakarta, Indonesia, 2013.

9. National Institute for Health Research and Development. Laporan Riset Kesehatan Dasar Indonesia; National Institute for Health Research and Development: Jakarta, Indonesia, 2007.

10. Kartono, D.; Atmarita, A.B.J.; Soekirma, D.I. Pregnant women in poor rural areas of Indonesia have low iodine intakes. IDD Newsl. 2017, 45, 11-12.

11. United Nations Children's Fund (UNICEF); Micronutrient Initiative. Review of Progress towards the Sustained Elimination of Iodine Deficiency Disorders in Indonesia; UNICEF: Jakarta, Indonesia, 2017. 
12. World Development Indicators. The World Bank. Available online: http://wdi.worldbank.org/table/3.12 (accessed on 3 March 2017).

13. The World Bank. Indonesia's Urban Story; World Bank Group: Washington, DC, USA, 2016.

14. Reardon, T.; Tschirley, D.; Dolislager, M.; Snyder, J.; Hu, C.; White, S. Urbanization, Diet Change, and Transformation of Food Supply Chains in Asia; Global Center for Food System Innovation: East Lansing, MI, USA, 2014.

15. Regmi, A.; Dyck, J. Effects of urbanization on global food demand. In Changing Structure of Global Food Consumption and Trade; U.S. Department of Agriculture, Agriculture and Trade Report: Washington, DC, USA, 2001; pp. 23-30.

16. Euromonitor International. Packaged Food in Indonesia. Country Report. 2016. Available online: http: / / www.euromonitor.com/packaged-food-in-indonesia/report (accessed on 28 March 2017).

17. Euromonitor International. Sauces, Dressings and Condiments in Indonesia. Country Report. 2016. Available online: http:/ / www.euromonitor.com/sauces-dressings-and-condiments-in-indonesia/report (accessed on 28 March 2017).

18. PT Clarity Research; National Agency of Drugs and Food Control; Ministry of Health. Usage of Iodized Salt in Processed Food in Indonesia; Gain: Jakarta, Indonesia, 2014.

19. National Institute for Health Research and Development. Studi Diet Total: Survei Konsumsi Makanan Individu Indonesia 2014; National Institute for Health Research and Development: Jakarta, Indonesia, 2014.

20. Indonesia Consumed 13.2 Billion Instant Noodle Packages in 2015. Indonesia Investments. Available online: http:/ / www.indonesia-investments.com/news/todays-headlines/indonesia-consumed13.2-billion-instant-noodle-packages-in-2015/item6815 (accessed on 29 September 2016).

21. Top Brand Award. Available online: http://www.topbrand-award.com/top-brand-survey/survey-result/ top-brand-index-2013 (accessed on 29 September 2016).

22. International Council for Control of Iodine Deficiency Disorders; United Nations Children's Fund (UNICEF); World Health Organization (WHO). Assessment of Iodine Deficiency Disorders and Monitoring Their Elimination: A Guide for Programme Managers; World Health Organization (WHO): Geneva, Switzerland, 2007.

23. Pedoman Biomedis: RISKESDAS 2013. Guideline for Biomedical Analyses. Available online: http:/ / perpustakaan.litbang.depkes.go.id/otomasi/index.php?p=show_detail\&id=32326 (accessed on 2 August 2016).

24. Euromonitor International. Rice, Pasta and Noodles in Indonesia. 2014. Available online: http://www. euromonitor.com/rice-pasta-and-noodles-in-indonesia/report (accessed on 28 March 2017).

25. Bimo, B.; (Large Scale Food Fortification Initiative, Global Alliance for Improved Nutrition, Jakarta, Indonesia); Global Alliance for Improved Nutrition; (Jakarta, Indonesia). Personal communication, 2017.

26. Ministry of Health. Regulation Number 75/2013 on Recommended Dietary Allowances; Ministry of Health: Jakarta, Indonesia, 2013.

27. World Health Organization. Guideline: Fortification of Food-Grade Salt with Iodine for the Prevention and Control of Iodine Deficiency Disorders; World Health Organization (WHO): Geneva, Switzerland, 2014.

28. United Nations Children's Fund (UNICEF); Iodine Global Network (IGN). Technical Working Group Meeting on Research Priorities for the Monitoring of Salt Iodization Programs and Determination of Population Iodine Status; UNICEF: New York, NY, USA, 2016.

29. Spohrer, R.; Larson, M.; Maurin, C.; Laillou, A.; Capanzana, M.; Garrett, G.S. The growing importance of staple foods and condiments used as ingredients in the food industry and implications for large-scale food fortification programs in Southeast Asia. Food Nutr. Bull. 2013, 34, S50-S61. [CrossRef] [PubMed]

30. Spohrer, R.; Garrett, G.S.; Timmer, A.; Sankar, R.; Kar, B.; Rasool, F.; Locatelli-Rossi, L. Processed foods as an integral part of universal salt iodization programs: A review of global experience and analyses of Bangladesh and Pakistan. Food Nutr. Bull. 2012, 33, S272-S280. [CrossRef] [PubMed]

31. James, W.P.; Ralph, A.; Sanchez-Castillo, C. The dominance of salt in manufactured food in the sodium intake of affluent societies. Lancet 1987, 329, 426-429. [CrossRef]

(C) 2018 by the authors. Licensee MDPI, Basel, Switzerland. This article is an open access article distributed under the terms and conditions of the Creative Commons Attribution (CC BY) license (http:/ / creativecommons.org/licenses/by/4.0/). 